\title{
Slik gir du godt munnstell til kreftpasienten
}

Cellegift kan medføre smertefulle sår i slimhinnene, munntørrhet og kvalme. Da er det en utfordring å opprettholde god munnhygiene.

\section{Forfatter}

Lise Thorsen

Spesialtannpleier

Tannhelsetjenestens kompetansesenter Vest Hordaland, Helse Bergen og Kjevekirurgisk avdeling, Haukeland universitetssykehus

munnhuleproblemer

Kreft

munnstell

Sykepleien 2018 106(71809)(e-71809)

DOI: https://doi.org/10.4220/Sykepleiens.2018.71809

\section{Hovedbudskap}

Pasienter som behandles for kreft, får ofte problemer med munnhule og tannhelse både i løpet av kreftbehandlingen og i tiden etter. De orale bivirkningene kan variere i omfang, fra ubehag til problemer som kan ha betydning for kreftbehandlingen og pasientens generelle helse. Men det finnes tiltak som kan lindre plagene.

Munnhuleproblemer i forbindelse med kreftbehandling kan være akutte eller kroniske. De akutte oppstår i forbindelse med kreftbehandlingen og går tilbake etterpå. Hyppigst er sår i slimhinner og munntørrhet.

De kroniske problemene oppstår også i behandlingsperioden, men går ikke tilbake etter endt behandling. 
Eksempler på dette kan være munntørrhet hos pasienter som har fått strålebehandling mot hode- eller halsområdet. Strålereaksjonene i slimhinner og hud går stort sett tilbake, mens munntørrheten ofte vedvarer og påvirker tannhelsen negativt. Mange behøver ekstra tiltak resten av livet for å kunne opprettholde en akseptabel tannhelse.

\section{Akutte reaksjoner}

De fleste munnhuleplager relatert til annen kreftsykdom enn hode-/halskreft oppstår i behandlingsperioden og går tilbake etterpå (1).

Under strålebehandlingen vil det oppstå akutte reaksjoner, hvorav betennelse i munnslimhinnen, mucositt, og munntørrhet er hyppigst forekommende. Stråleindusert mucositt er smertefulle, tidvis ulcererende områder i slimhinnene i strålefeltet.

\section{ulcerasjon}

«Ulcerasjon er et sår, en defekt i huden som går ned i dermis (lærhuden).»

Kilde: Store medisinske leksikon

Sårheten sees vanligvis etter omtrent ti strålebehandlinger og øker gradvis i intensitet mot slutten av behandlingen. Strålereaksjonene vil så avta i ukene etter avsluttet behandling.

Akuttreaksjonene kan ikke unngås, men kan reduseres og lindres ved at pasientene har gode munnhygienerutiner. I sluttfasen av strålebehandlingen vil mange pasienter ikke klare å pusse tennene selv. Da er det viktig at pleiepersonellet yter praktisk hjelp.

\section{三 «Vansker med tannpuss på grunn av smertefulle sår i slimhinnene, munntørrhet og kvalme er velkjent.»}


Munntørrheten som oppstår ved cellegiftbehandling, er vanligvis reversibel, og slimhinnesårene som oppstår ved noen former for cellegift, vil gå tilbake etter endt kreftbehandling. Vansker med tannpuss på grunn av smertefulle sår i slimhinnene, munntørrhet og kvalme er velkjent.

\section{Sårbare for infeksjoner}

Spyttsekresjonen kan reduseres på grunn av medisinbruken, og dette fører til dårligere bufring av syre fra munnhulebakterier. Kariesaktiviteten kan derfor øke. Allerede etablert tannkjøttbetennelse, gingivitt eller periodontitt, kan blusse kraftig opp når kroppens forsvar mot infeksjon svekkes. I tillegg er det vist oppvekst av spesielt hissige mikroorganismer i munnhulen når immunforsvaret er svakt på grunn av leukopeni (2).

\section{gingivitt og periodontitt}

«Gingivitt, en tilstand som forårsaker

blødning, hevelse og noe ubehag men ikke

skade på tannens festeapparat

(periodontium). Spredning av denne

tannkjøttbetennelsen nedover i rothinnen

(marginal periodontitt) gjør at tennenes

festeapparat brytes ned, og etter hvert som

mer og mer feste blir betent og bukker under

for den nedbrytende infeksjonen blir tannen

så løs at den må fjernes av tannlegen

(extraheres) eller faller ut av seg selv.»

Kilde: Store medisinske leksikon

I denne situasjonen er det spesielt viktig å hemme bakterieveksten ved hjelp av god munnhygiene. Enkelt sagt skal det færre munnhulebakterier til for at det oppstår en infeksjon når man er påvirket av sykdom og immunsuppressiv behandling enn under normale forhold. 
Blir det vanskelig å pusse med en vanlig myk tannbørste, finnes det supermyke børster å få tak i på apotek, for eksempel TePe special care. Vi har god erfaring med bruk av disse børstene til pasienter som har perioder med lave blodverdier, eller som har vonde slimhinnesår.

\section{Avgjørende hygiene}

I tillegg til tannpuss med børste anbefales det også for disse pasientgruppene milde munnskyllevæsker, ekstra tilskudd av fluor og stimulering av salivproduksjonen.

God munnhygiene er essensielt. Tannbørste er det enkleste og mest effektive redskapet til å rengjøre tenner og tunge (3). Ved normale forhold er munnslimhinnene stort sett selvrensende på grunn av bevegelse av ansikts- og kjevemuskulaturen samt salivas stadige fukting og smøring av overflatene. Når det er mindre tunge- og muskelbevegelser samt mindre mengde og ofte seigere saliva, øker opphopningen av plakk.

\section{三 «Pleiepersonell må ofte gå aktivt inn og utføre munnstell.»}

Det krever at munnhygienen intensiveres.

Pleiepersonell må ofte gå aktivt inn og utføre munnstell, slik at slimhinner blir renset i tillegg til tenner og tunge. Ved siden av tannbørste er låsbar pinsett og tupfere gode hjelpemidler.

I perioder kan munnstell være vanskelig å gjennomføre på grunn av smerter eller kvalme. Skylling med en mild skyllevæske i en skyllesprøyte kan være lindrende, samtidig som matrester og slim skylles ut. Prinsippet er at det er bedre å gjøre litt enn å unngå å gjøre noe.

\section{Behov for forskning}


Valg av midler til rensing og smøring av munnhulen baserer seg i stor grad på empiri og med noe støtte i den litteraturen som foreligger. En grundig gjennomgang av tilgjengelig litteratur på området gir ikke grunnlag for å hevde at en spesiell behandling er evidensbasert, slik en gjerne skulle ønske. Det er altså behov for forskning på området (4). Midlene som anbefales, må ha en ønsket effekt, samtidig som de ikke har påviselige negative effekter i den konsentrasjonen de brukes.

Munnskyllevæsker til denne pasientgruppen bør ikke inneholde alkohol eller sterke smakstilsetninger. Det vil irritere slimhinnene ytterligere og tolereres dårlig av pasientene. Sterke løsninger av klorhexidin (2 prosent) er eksempel på dette, selv om den antibakterielle effekten er veldokumentert.

\section{Erfaringer fra bruk}

Mucositt kan oppleves forskjellig fra person til person. Smak og behag er som kjent også forskjellig. Derfor er vi stadig på jakt etter munnpleiemidler som virker lindrende ved såre og tørre slimhinner, samtidig som smaken tolereres av flest mulig.

Hydrogenperoksidløsning 0,5 (1 del hydrogenperoksid 3 prosent og 5 deler vann) er mild og virker rensende og slimløsende.

Fysiologisk saltvann 0,9 prosent virker svakt rensende og slimløsende.

Andolex munnskyllevæske inneholder benzydaminklorid og har antiinflammatoriske og lokalanestetiske egenskaper.

Flux dry mouth rinse lindrer munntørrhet. Egen klinisk erfaring viser at den også lindrer mucosittplager. 
Glyserolblanding 17 prosent (1 del glyserol 85 prosent og

4 deler vann) bevarer fuktighet og kan bidra til lindring av slimhinnesår.

Salivstimulerende og smørende sprayer produseres av flere fabrikanter og finnes på de fleste apoteker. Det samme gjelder forskjellige typer geleer som kan gi fukt og lindring.

\section{Typer munnpleiemidler}

Mange pasienter under behandling opplever såre og sprukne lepper. God leppepleie er en viktig del av munnstellet. Mange gode, pleiende kremer finnes på de fleste apotek. Bruk av tannkrem kan være utfordrende fordi de fleste typer har for sterk smak for pasienter med mucositt og munntørrhet.

\section{三 «Mucosittplager krever hyppige tiltak.»}

I tillegg har forskning vist at et vanlig brukt såpestoff i tannkrem, sodiumlaurylsulfat (SLS), virker uttørrende på slimhinner (5). Vi anbefaler derfor tannkrem med nøytralt såpestoff til pasienter med munntørrhet og andre slimhinneproblemer.

Eksempler på denne typen tannkrem er Zendium, Salutem og Sensodyne.

Mucosittplager krever hyppige tiltak, men avpasses i forhold til alvorlighetsgrad av plagene. Det er derfor fint om vi kan anbefale flere typer munnpleiemidler, slik at pasientene kan variere i løpet av døgnet.

\section{Referanser}

1. Skår R, Løes IM, Thorsen L, Afnan S, Løes S. Cytostatika og oral helse. Nor Tannlegeforen Tidende. 2010;120(14):968-73. 
2. Maschmeyer G, Haas A. The epidemiology and treatment of infections in cancer patients. Int $\mathrm{J}$

Antimicrob Agents. 2008 mars;31(3):193-7.

3. Pearson LS, Hutton JL. A controlled trial to compare the ability of foam swabs and toothbrushes to remove dental plaque. J Adv Nurs. 2002 september;39(5):480-9.

4. Rubenstein EB, Peterson DE, Schubert M, Keefe D, McGuire D, Epstein J, et al. Clinical practice guidelines for the prevention and treatment of cancer therapy-induced oral and gastrointestinal mucositis. Cancer. 2004 mai;100(S 9):2026-46.

5. Herlofson BB. Sodium lauryl sulfate: clinical and biological effects of a toothpaste detergent. (Doktoravhandling.) Oslo: Department of Oral Surgery and Oral Medicine, Department of Oral Biology, Dental Faculty, University of Oslo, 1996. 